\title{
Myxomycetes recorded from three lowland tropical forests in Vietnam
}

\author{
Tran DQ ${ }^{1}$, Nguyen HTN ${ }^{1}$, Tran HTM ${ }^{1}$ and Stephenson $\mathrm{SL}^{2}$ \\ ${ }^{1}$ School of Biotechnology, Ho Chi Minh International University, Thu Duc, Ho Chi Minh City, Vietnam \\ ${ }^{2}$ Department of Biological Sciences, University of Arkansas, Fayetteville, Arkansas 72701
}

Tran DQ, Nguyen HTN, Tran HTM, Stephenson SL 2014 - Myxomycetes from three lowland tropical forests in Vietnam. Mycosphere 5(5), 662-672, Doi 10.5943/mycosphere/5/5/7

\begin{abstract}
The first report of myxomycetes from Vietnam was in 2009 by van Hooff, who listed 23 species, including one (Cribraria tecta) new to science, from moist chamber cultures prepared with samples of dead leaves, lychee husks, woody twigs and herbaceous stems. Two other species, both new to science, were reported in a recent paper. The project reported herein investigated the occurrence of myxomycetes in moist chamber cultures prepared with samples of various types of dead plant material collected in three lowland tropical forests in Vietnam. These samples were randomly collected from Cuc Phuong, Bu Gia Map and Nam Cat Tien national parks in the late dry season or between the dry season and the rainy season during 2012 and 2013. From 360 moist chambers, 43 species of myxomycetes representing 19 genera were recorded. The most abundant species were Arcyria cinerea, Collaria arcyrionema, Cribraria microcarpa, Cribraria violacea, Perichaena chrysosperma and Perichaena depressa. The taxonomic composition of the assemblage of species associated with the three study areas was found to be similar to what has been reported from Laos, Myanmar and Thailand, the other regions of SE Asia for which comparable studies have been carried out. In brief, the present project added 32 new records of myxomycetes for Vietnam, increasing the total number of species known from the country to 57.
\end{abstract}

Key words - biodiversity - dead plant material - national parks - Southeast Asia - slime molds

\section{Introduction}

The myxomycetes (plasmodial slime molds or myxogastrids) are a group of fungus-like microorganisms common to sometimes abundant in terrestrial ecosystems (Martin \& Alexopoulos 1969, Stephenson \& Stempen 1994, Stephenson 2011). In order for fruiting bodies to develop from the plasmodia that represent the second of the two trophic stages in their life cycle, myxomycetes generally require relatively moist conditions. As such, the dry season is not an especially favorable period during which to collect specimens of fruiting bodies that have developed under natural conditions in the field. However, the moist chamber culture technique as it applies to myxomycetes (Gilbert \& Martin 1933) provides a convenient and often very productive method of supplementing field collections (Stephenson 1989). This is especially true for many of the substrates with which myxomycetes are associated in tropical forests (Rojas et al. 2014), such as those substrates investigated in the present study. 
Vietnam is situated within the tropical zone, but the country can be divided into three regions-the north, central coast and south-on the basis of climate. The north has a humid subtropical climate, the central coast is characterized by a tropical monsoon climate, and the south has a tropical monsoon and trade-wind littoral climate. The latter region is characterized by two distinct seasons. The first is a dry season that extends from December to April and the second is a rainy season that lasts from May to November. The latter season is characterized by high humidity (usually around $80 \%$ ) and high temperatures (occasionally $<20^{\circ} \mathrm{C}$ but often reaching $40^{\circ} \mathrm{C}$ ).

Unlike the large body of information on myxomycetes that has been compiled for temperate regions of the world such as eastern North America and Europe, the myxomycetes of Southeast Asia remain understudied. The two countries for which the most is known are Thailand and the Philippines. In Thailand, a recent study reported a total of 132 species of myxomycetes in 20 genera (Ko Ko et al. 2010), whereas 129 species have been recorded for the Philippines (Dagamac et al. 2011, Macabago et al. 2012). For other areas in Southeast Asia, the totals range from 119 species for Indonesia (Farr 1990, Rosing et al. 2011), 76 for the Republic of Singapore (Rosing et al. 2011), 67 for Myanmar (Ko Ko et al. 2013a) to 44 species for Laos (Ko Ko et al. 2013b). The first report of myxomycetes from Vietnam was by van Hooff (2009), who listed a total of 23 species, including one (Cribraria tecta) new to science. These 23 species were obtained from 20 moist chamber cultures prepared with samples of dead leaves, lychee husks, woody twigs and herbaceous stems. A recent paper by Novozhilov et al. (2014) added two more species from Vietnam, and both of these were new to science. Based on the data available for other comparable regions of Southeast Asia, there is little doubt that many more species remain to be documented for the country, and the objective of the present paper is to report the results obtained from an additional survey for myxomycetes carried out in three national parks during 2012 and 2013.

\section{Materials \& Methods}

\section{Study areas}

Study areas were selected in three national parks in Vietnam. The description of each of these parks is given below.

(1) Bu Gia Map National Park (BGM) is located at an elevation of approximately $600 \mathrm{~m}$ in Binh Phuoc Province and has a total extent of 26032 ha. In 2007, the Institute of Tropical Biology and National Parks reported 808 species, 396 genera, 118 families and 59 orders of vascular plants present in the park (Anonymous 1997). The specific study area is located at $12.2917^{\circ} \mathrm{N}, 107.2417^{\circ}$ E.

(2) Cuc Phuong National Park (CP) occurs at an elevation of about $600 \mathrm{~m}$ and has a total area of 22200 ha in Ninh Binh Province. The vascular flora of this park contains at least 1960 species, 887 orders and 221 families (Nguyen 1997). The specific study area is located at 20.3189 $\mathrm{N}, 105.6222^{\circ} \mathrm{E}$.

(3) Nam Cat Tien National Park (NCT) is located at an elevation of approximately $600 \mathrm{~m}$ and extends over 71350 ha in Dong Nai Province. As of 2001, there were 1610 species, 724 genera, 162 families and 75 orders of vascular plants known from this park (UNESCO 2001). The specific study area is located at $11.3472^{\circ} \mathrm{N}, 107.0014^{\circ} \mathrm{E}$.

\section{Sample collection}

All study areas were visited in the late dry season or between the dry season and the rainy season during 2012 and 2013. Samples of various types of dead plant material, including dead leaves, dead bark, lianas and woody twigs, were collected from randomly selected localities. These samples were brought back to the laboratory and used to prepare moist chamber cultures following the method described by Stephenson \& Stempen (1994). A total of 120 moist chamber cultures were prepared with sample material from each study area. These cultures were placed on horizontal shelves under diffuse daylight and maintained at room temperature. Water was added when necessary to maintain moist conditions, and the cultures were checked twice each week for 
evidence (either plasmodia or fruiting bodies) of myxomycetes for a period of three months. When fruiting bodies were observed, they were recorded, removed from the moist chamber culture, airdried and placed in small pasteboard boxes for long-term storage.

Myxomycetes were identified to species using standard monographs (e.g., Martin \& Alexopoulos 1969) of the group. The morphological species concept (sensu Stephenson 2003) is the one used herein, and nomenclature follows Lado (2005-2014).

\section{Evaluation of myxomycete abundance}

The relative abundance of each species of myxomycete in each of the three study areas was calculated using the abundance index (\%), which is derived by dividing the number of specimens of a particular species by the total number of specimens of all species and multiplying the resulting value by 100 . Based on the calculated values, the occurrence of each species was ranked as "rare" (for species representing less than $0.5 \%$ of the total number of specimens for a particular study area), "occasional" (species representing more than $0.5 \%$ but less than $1.5 \%$ of the total number of specimens), "common" (species representing more than $1.5 \%$ but less than $3.0 \%$ of the total number of specimens) or "abundant" (species representing more than $3.0 \%$ of the total number of specimens) in the manner described by Stephenson et al. (1989) and Tran et al. (2006).

\section{Results}

\section{Distribution of myxomycetes in three study areas}

Species of myxomycetes appearing in the moist chamber cultures and their calculated abundance indices are listed in Table 1. In total, 43 species belonging to 19 genera were recorded. Samples from Cuc Phuong National Park yielded 25 species, those from Nam Cat Tien National Park yielded 28 species and those from Bu Gia Map National Park yielded 25 species. Ten species were recorded in all three parks (Table 1). Overall, the most abundant species were Arcyria cinerea, Collaria arcyrionema, Cribraria microcarpa, Cribraria violacea, Perichaena chrysosperma and Perichaena depressa.

\section{List of myxomycetes currently known from Vietnam}

As noted earlier in this paper, the only previous records of myxomycetes from Vietnam of which we are aware are the 23 species listed by van Hooff and the two species new to science listed by Novozhilov et al. (2014). Eleven of these 25 species (marked by the symbol "*" in Table 1) already known to occur in Vietnam were recorded in the present study along with 32 other species that represent new records for the country. This brings the total number of myxomycetes currently known from Vietnam to 57. An annotated list of these 57 species is provided below. In addition, the source of the first record for each species is given, along with information relating to the distribution of the species in question.

Arcyria cinerea (Bull.) Pers.

The most common species in the present study ( 21 records) and also recorded by van Hooff (2009). Known distribution elsewhere in SE Asia: Laos, Myanmar and Thailand. This is one of the most common of all species of myxomycetes.

Arcyria denudata (L.) Wettst.

First recorded from Vietnam in the present study (2 records). Known distribution elsewhere in SE Asia: Laos and Myanmar.

Arcyria insignis Kalchbr. \& Cooke

First recorded from Vietnam in the present study (3 records). Known distribution elsewhere in SE Asia: Thailand. 
Table 1 Distribution of myxomycetes recorded from study areas in the three national parks.

\begin{tabular}{|c|c|c|c|}
\hline \multirow{2}{*}{ Species } & \multicolumn{3}{|c|}{ National Park } \\
\hline & Bu Gia Map & Nam Cat Tien & Cuc Phuong \\
\hline *Arcyria cinerea & A & A & A \\
\hline Arcyria denudata & - & $\mathrm{R}$ & $\mathrm{R}$ \\
\hline Arcyria insignis & - & - & $\mathrm{R}$ \\
\hline Calomyxa metallica & - & - & $\mathrm{R}$ \\
\hline Ceratiomyxa fruticulosa & $\mathrm{R}$ & $\mathrm{R}$ & $\mathrm{C}$ \\
\hline Clastoderma debaryanum & $\mathrm{R}$ & - & $\mathrm{R}$ \\
\hline Collaria arcyrionema & A & A & A \\
\hline Comatricha cf. alta & $\mathrm{O}$ & A & - \\
\hline *Comatricha tenerrima & $\mathrm{C}$ & $\mathrm{C}$ & $\mathrm{R}$ \\
\hline Craterium minutum & $\mathrm{R}$ & - & - \\
\hline Cribraria microcarpa & A & A & - \\
\hline Cribraria violacea & A & A & A \\
\hline Diachea leucopodia & - & $\mathrm{C}$ & - \\
\hline Diderma effusum & $\mathrm{O}$ & $\mathrm{O}$ & \\
\hline *Diderma hemisphaericum & - & - & $\mathrm{R}$ \\
\hline Diderma globosum & - & $\mathrm{C}$ & - \\
\hline Didymium nigripes & - & - & $\mathrm{C}$ \\
\hline Didymium squamulosum & $\mathrm{O}$ & $\mathrm{O}$ & - \\
\hline *Echinostelium minutum & - & - & $\mathrm{R}$ \\
\hline Hemitrichia calyculata & - & $\mathrm{O}$ & - \\
\hline Hemitrichia serpula & $\mathrm{C}$ & $\mathrm{C}$ & A \\
\hline *Lamproderma scintillans & $\mathrm{O}$ & $\mathrm{O}$ & - \\
\hline Licea operculata & - & - & $\mathrm{R}$ \\
\hline Metatrichia vesparia & - & - & $\mathrm{R}$ \\
\hline Perichaena chrysosperma & A & A & $\mathrm{C}$ \\
\hline Perichaena depressa & A & A & $\mathrm{C}$ \\
\hline *Perichaena vermicularis & - & $\mathrm{R}$ & $\mathrm{R}$ \\
\hline Physarum album & $\mathrm{R}$ & A & - \\
\hline Physarum bivalve & $\mathrm{C}$ & $\mathrm{O}$ & - \\
\hline Physarum bogoriense & $\mathrm{R}$ & - & - \\
\hline *Physarum cinereum & $\mathrm{R}$ & $\mathrm{R}$ & - \\
\hline *Physarum compressum & - & - & A \\
\hline Physarum crateriforme & - & - & $\mathrm{R}$ \\
\hline Physarum echinosporum & $\mathrm{R}$ & $\mathrm{R}$ & - \\
\hline Physarum flavicomum & $\mathrm{C}$ & $\mathrm{C}$ & - \\
\hline Physarum lakhanpalii & $\mathrm{R}$ & $\mathrm{R}$ & $\mathrm{R}$ \\
\hline *Physarum melleum & - & $\mathrm{R}$ & - \\
\hline *Physarum pusillum & - & $\mathrm{R}$ & $\mathrm{R}$ \\
\hline Physarum roseum & $\mathrm{O}$ & A & - \\
\hline Physarum superbum & - & - & $\mathrm{R}$ \\
\hline Physarum viride & - & - & $\mathrm{R}$ \\
\hline Stemonitis fusca & $\mathrm{R}$ & $\mathrm{C}$ & $\mathrm{C}$ \\
\hline *Stemonitis herbatica & $\mathrm{R}$ & - & - \\
\hline
\end{tabular}

Note: Abundance indices (described earlier in this paper) are $\mathrm{A}=$ abundant, $\mathrm{C}=$ common, $\mathrm{O}=$ occasional and $\mathrm{R}=$ rare. The symbol “*” indicates a species reported by van Hooff. 
Arcyria marginoundulata Nann.-Bremek. \& Y. Yamam

First reported from Vietnam by van Hooff (2009) and not recorded in the present study. Known distribution elsewhere in SE Asia: Laos.

Arcyria minuta Buchet

First reported from Vietnam by van Hooff (2009) but not recorded in the present study.

\section{Calomyxa metallica (Berk.) Nieuwl.}

First reported from Vietnam in the present study (1 record). Known distribution elsewhere in SE Asia: Myanmar.

Ceratiomyxa fruticulosa (O. F. Müll.) T. Macbr.

First reported from Vietnam in the present study (6 records). Known distribution elsewhere in SE Asia: Laos, Myanmar and Thailand.

\section{Clastoderma debaryanum A. Blytt}

First recorded from Vietnam in the present study (with 2 records). Known distribution elsewhere in SE Asia: Laos, Myanmar and Thailand.

Collaria arcyrionema (Rostaf.) Nann.-Bremek. ex Lado

First recorded from Vietnam in the present study (with 3 records). Known distribution elsewhere in SE Asia: Laos, Myanmar and Thailand.

\section{Comatricha cf. alta Preuss}

First recorded from Vietnam in the present study (6 records). Known distribution elsewhere in SE Asia: Thailand. These specimens are referred to this species on the basis of the loosely attached capillitium and the size of the spores but are characterized by a shorter stipe than is typical for Comatricha alta. However, they appear to fit this species better than any other species of which the last author is aware.

Comatricha brachypus (Meyl.) Meyl.

First reported from Vietnam by van Hooff (2009) and not recorded in the present study.

Comatricha tenerrima (M. A. Curtis) G. Lister

First reported from northern of Vietnam by van Hooff (2009) and also recorded in the present study (3 records). Known distribution elsewhere in SE Asia: Laos, Myanmar and Thailand.

Craterium minutum (Leers) Fr.

First recorded from Vietnam in the present study (1 record). Known distribution elsewhere in SE Asia: Thailand.

Cribraria microcarpa (Schrad.) Pers.

First recorded from Vietnam in the present study (14 records). Known distribution elsewhere in SE Asia: Laos, Myanmar and Thailand.

Cribraria tecta Hooff.

First reported, as a species new to science, from Vietnam by van Hooff (2009) and not recorded in the present study.

\section{Cribraria violacea Rex}

First recorded from Vietnam in the present study (18 records). Known distribution elsewhere in SE Asia: Laos, Myanmar and Thailand. 
Diachea leucopodia (Bull.) Rostaf.

First recorded from Vietnam in the present study (2 records). Known distribution elsewhere in SE Asia: Laos, Myanmar and Thailand.

Diderma cattiense Novozh. \& D. W. Mitch.

First recorded from Vietnam by Novozhilov et al. (2014) and not recorded in the present study. Currently known only from Vietnam.

Diderma effusum (Schwein.) Morgan

First recorded from Vietnam in the present study (5 records). Known distribution elsewhere in SE Asia: Laos, Myamar and Thailand.

Diderma globosum Pers.

First recorded from Vietnam in the present study (1 record).

Diderma hemisphaericum (Bull.) Hornem.

First reported from Vietnam by van Hooff (2009) and also recorded in the present study (1 record). Known distribution elsewhere in SE Asia: Laos, Myanmar and Thailand.

Diderma pseudotestaceum Novozh. \& D. W. Mitch.

First recorded from Vietnam by Novozhilov et al. (2014) and not recorded in the present study. Currently known only from Vietnam.

Diderma saundersii (Berk. \& Broome ex Massee) E. Sheld.

First reported from Vietnam by van Hooff (2009) and not recorded in the present study. Known distribution elsewhere in SE Asia: Myanmar.

Didymium bahiense Gottsb.

First reported from Vietnam by van Hooff (2009) and not recorded in the present study. In his paper, van Hooff listed both the typical variety and the variety microsporum Hochg., Gottsb. \& Nann.-Bremek. Known distribution elsewhere in SE Asia: Thailand.

Didymium difforme (Pers.) Gray

First reported from Vietnam by van Hooff (2009) and not recorded in the present study. Known distribution elsewhere in SE Asia: Myanmar and Thailand.

Didymium nigripes (Link) Fr.

First recorded from Vietnam in the present study (3 records). Known distribution elsewhere in SE Asia: Thailand. This species is morphologically very similar to Didymium iridis (Ditmar) Fr., and both are members of a group of long-stalked species of Didymium that also includes D. bahiense.

Didymium squamulosum (Alb. \& Schwein.) Fr. \& Palmquist

First recorded from Vietnam in the present study (3 records). Known distribution elsewhere in SE Asia: Laos, Myanmar and Thailand.

Echinostelium minutum de Bary

First reported from Vietnam by van Hooff (2009) and also recorded in the present study (1 record). Known distribution elsewhere in SE Asia: Myanmar and Thailand.

Hemitrichia calyculata (Speg.) M. L. Farr

First recorded from Vietnam in the present study (4 records). Known distribution elsewhere 
in SE Asia: Laos, Myanmar and Thailand.

Hemitrichia serpula (Scop.) Rostaf. ex Lister

First recorded from Vietnam in the present study (8 records). Known distribution elsewhere in SE Asia: Laos, Myanmar and Thailand.

Lamproderma scintillans (Berk. \& Broome) Morgan

First reported from Vietnam by van Hooff (2009) and also recorded in the present study (8 records). Known distribution elsewhere in SE Asia: Laos, Myanmar and Thailand.

Licea operculata (Wingate) G. W. Martin

First recorded from Vietnam in the present study (1 record). Known distribution elsewhere in SE Asia: Myanmar and Thailand.

Metatrichia vesparia (Batsch) Nann.-Bremek. ex. G.W. Martin \& Alexop.

First recorded from Vietnam in the present study (3 records). Known distribution elsewhere in SE Asia: Laos and Myanmar.

Paradiachea caespitosa (Sturgis) Hertel ex H. Neubert, Nowotny \& K. Baumann

First reported from Vietnam by van Hooff (2009) and not recorded in the present study.

Perichaena chrysosperma (Curr.) Lister

First recorded from Vietnam in the present study (8 records). Known distribution elsewhere in SE Asia: Myanmar and Thailand.

Perichaena corticalis (Batsch) Rostaf.

First reported from Vietnam by van Hooff (2009) but not recorded in the present study. Known distribution elsewhere in SE Asia: Thailand.

Perichaena depressa Lib.

First recorded from Vietnam in the present study (4 records). Known distribution elsewhere in SE Asia: Laos, Myanmar and Thailand.

Perichaena vermicularis (Schwein.) Rostaf.

First reported from Vietnam by van Hooff (2009) and also recorded in the present study (1 record). Known distribution elsewhere in SE Asia: Myanmar and Thailand.

Physarum album (Bull.) Chevall.

First recorded from Vietnam in the present study (6 records). Known distribution elsewhere in SE Asia: Myanmar and Thailand.

Physarum bivalve Pers.

First recorded from Vietnam in the present study (12 records). Known distribution elsewhere in SE Asia: Thailand.

Physarum bogoriense Racib.

First recorded from Vietnam in the present study (1 record). Known distribution elsewhere in SE Asia: Thailand.

Physarum cinereum (Batsch) Pers.

First reported from Vietnam by van Hooff (2009) and also recorded in the present study (2 records). Known distribution elsewhere in SE Asia: Laos, Myanmar and Thailand. 
Physarum compressum Alb. \& Schwein.

First reported from Vietnam by van Hooff (2009) and also recorded in the present study (5 records). Known distribution elsewhere in SE Asia: Laos and Thailand.

\section{Physarum crateriforme Petch}

First recorded from Vietnam in the present study (1 record). Known distribution elsewhere in SE Asia: Laos, Myanmar and Thailand.

\section{Physarum echinosporum Lister}

First recorded from Vietnam in the present study (11 records). Known distribution elsewhere in SE Asia: Laos and Thailand.

\section{Physarum flavicomum Berk.}

First recorded from Vietnam in the present study (2 records). Known distribution elsewhere in SE Asia: Thailand.

\section{Physarum gyrosum Rostaf.}

First recorded from Vietnam by van Hooff (2009) and not recorded in the present study. Known distribution elsewhere in SE Asia: Thailand.

Physarum lakhanpalii Nann.-Bremek. \& Y. Yamam.

First recorded from Vietnam in the present study (1 record). Known distribution elsewhere in SE Asia: Laos, Myanmar and Thailand.

Physarum melleum (Berk. \& Broome) Massee

First reported from Vietnam by van Hooff (2009) and also recorded in the present study (2 records). Known distribution elsewhere in SE Asia: Laos, Myanmar and Thailand.

\section{Physarum oblatum T. Macbr.}

First reported from Vietnam by van Hooff (2009) and also recorded in the present study (1 record). Known distribution elsewhere in SE Asia: Thailand.

Physarum pusillum (Berk. \& M. A. Curtis) G. Lister

First reported from Vietnam by van Hooff (2009) and also recorded in the present study (3 records). Known distribution elsewhere in SE Asia: Laos, Myanmar and Thailand.

Physarum roseum Berk. \& Broome

First recorded from Vietnam in the present study (10 records). Known distribution elsewhere in SE Asia: Thailand.

\section{Physarum superbum Hagelst.}

First recorded from Vietnam in the present study (1 record). Known distribution elsewhere in SE Asia: Laos and Thailand.

Physarum viride (Bull.) Pers.

First recorded from Vietnam in the present study (1 record). Known distribution elsewhere in SE Asia: Laos, Myanmar and Thailand.

Stemonaria fuscoides Nann.-Bremek. \& Y. Yamam.

First recorded from Vietnam by van Hooff (2009) and not recorded in the present study. 


\section{Stemonitis fusca Roth}

First recorded from Vietnam in the present study (6 records). Known distribution elsewhere in SE Asia: Myanmar and Thailand.

\section{Stemonitis herbatica Peck}

First recorded from Vietnam by van Hooff (2009) and also recorded in the present study (1 record). Known distribution elsewhere in SE Asia: Laos, Myanmar and Thailand.

\section{Taxonomic distribution of myxomycetes}

The distribution of species of myxomycete among the six taxonomic orders traditionally recognized for these organisms is not the same for all types of ecosystems (Stephenson et al. 1993), and a predominance of members of the Physarales in tropical/subtropical regions of the world has been noted in a number of previous studies (Martin 1940). For example, Schnittler \& Stephenson (2000) reported that the Physarales represented 55\% of the species of myxomycetes recorded from tropical dry forest, $45 \%$ from tropical rainforest, $76 \%$ from tropical wet forest and $77 \%$ from cloud forest in a major study carried out in Costa Rica. As was the case in the present study, these data were obtained with the use of the moist chamber culture technique. The data reported herein from Vietnam conform to this pattern, and the same is true for the sets of data available for Laos, Myanmar and Thailand (Table 2). Although the majority of the species represented in all three sets of data were recorded from moist chamber cultures, each set also included some species recorded as field collections.

Table 2 Distribution (\% of the total) among the six taxonomic orders for the species of myxomycetes recorded from the present study and three other studies carried out in the same general region of Southeast Asia. The data for Laos, Myanmar and Thailand are from Ko Ko et al. (2013a), Ko Ko et al. (2013b) and Ko Ko et al. (2010), respectively.

\begin{tabular}{lcccc}
\hline Order & Present study & Laos & Myanmar & Thailand \\
\hline Ceratiomyxales & 1.8 & 2.3 & 1.5 & 0.7 \\
Echinosteliales & 3.5 & 2.3 & 4.5 & 1.5 \\
Liceales & 7.0 & 6.8 & 19.4 & 13.7 \\
Physarales & 49.1 & 54.5 & 31.3 & 48.1 \\
Stemonitales & 15.8 & 20.5 & 17.9 & 19.1 \\
Trichiales & 22.8 & 13.6 & 25.4 & 16.8 \\
\hline
\end{tabular}

Although the order Physarales was clearly dominant, representatives of three other orders were sometimes rather common. This was the case for Arcyria cinerea (Trichiales), Collaria arcyrionema (Stemonitales) and Cribraria microcarpa (Liceales), which also were among the most common species appearing in moist chamber cultures prepared with forest floor litter from lowland tropical forests of northern Thailand (Tran et al. 2008). In the latter study, 33 species were recorded from 240 moist chamber cultures prepared with samples collected during the dry season, which is lower than the total recorded in the present study. Presumably, this is a result of the wider range of substrates used to prepare moist chambers in the present study and the different times of the year when the substrates were collected.

In summary, 43 species representing 19 genera were recorded from 360 moist chambers prepared with samples of various types of dead plant material collected in three different lowland tropical forests in Vietnam during 2012 and 2013. Thirty-two of these were new records for the country, thus bringing the total number of species known from Vietnam to 57 species. However, there is little doubt that many other species will be recorded as additional survey work involving both field collecting as well as the use of moist chamber cultures is carried out, as has been done in countries such as Thailand and the Philippines. In these two countries, the number of myxomycetes reported thus far is more than twice the total currently known from Vietnam. 


\section{Acknowledgements}

This research was supported in part by the International Foundation for Science, Stockholm, Sweden, through a grant to Hanh T. M. Tran.

\section{References}

Anonymous. 1997 - Nature elements of Bu Gia Map Nature Reserve. Unpublished report to the Binh Phuoc Provincial Department of Science, Technology and the Environment. [In Vietnamese]

Dagamac NHA, dela Cruz TEE, Pangilinan MVB, Stephenson SL. 2011 - List of species collected and interactive database of myxomycetes (plasmodial slime molds) for Mt. Arayat National Park, Pampanga, Philippines. Mycosphere 2, 449-455.

Farr ML. 1990 - Myxomycetes. In: Contributions toward a Mycobiota of Indonesia: Hypocreales, synnematous hyphomycetes, Aphyllophorales, Phragmobasidiomycetes, and Myxomycetes. Memoirs of the New York Botanical Garden 59, 169-171.

Gilbert HC, Martin GW 1933 - Myxomycetes found on the bark of living trees. University of Iowa Studies in Natural History 15, 3-8.

Ko Ko TW, Rosing WC, Ko Ko ZZW, Stephenson SL. 2013a - Myxomycetes of Myanmar. Sydowia 65, 267-276.

Ko Ko TW, Tran HTM, Clayton ME, Stephenson SL 2013b - First records of myxomycetes from Laos. Nova Hedwigia 96(1-2), 73-81.

Ko Ko TW, Tran HTM, Stephenson SL, Mitchell DW, Rojas C, Hyde KD, Lumyong S, Bahkali AH. 2010 - Myxomycetes of Thailand. Sydowia 62, 243-260.

Lado C. 2005-2014 - An online nomenclatural information system of Eumycetozoa. http://www.nomen.eumycetozoa.com (accessed on 10 August 2014).

Macabago SAB, dela Cruz TEE, Stephenson SL. 2012 - First records of myxomycetes from Lubang Island, Occidental Mindoro, Philippines. Sydowia 64, 109-118

Martin GW. 1940 - The myxomycetes. Botanical Review 6, 356-388.

Martin GW, Alexopoulos CJ. 1969 - The Myxomycetes. University of Iowa Press, Iowa City.

Nguyen TV. 1997 - The vegetation of Cuc Phuong National Park, Vietnam. Sida 17(4), 719-759.

Novozhilov YK, Mitchell DW, Okun MV, Shchepin ON. 2014. New species of Diderma from Vietnam. Mycosphere 5, 554-564.

Rojas C, Rollins AW, Stephenson SL. 2014 - Distribution of myxomycetes among the microhabitats available for these organisms in tropical forests. Pages 126-143 in Misra JK, Tewari JP, Deshmukh SK, Vágvölgyi C (eds.). Fungi From Different Substrates. CRC Press, Boca Raton, Florida.

Rosing WC, Mitchell DW, Moreno G, Stephenson SL. 2011 - Additions to the myxomycetes of Singapore. Pacific Science 65, 391-400.

Schnittler M, Stephenson SL. 2000 - Myxomycete biodiversity in four different forest types in Costa Rica. Mycologia 92(4), 626-637.

Stephenson SL. 1989 - Distribution and ecology of myxomycetes in temperate forests. II. Patterns of occurrence on bark surface of living trees, leaf litter, and dung. Mycologia 81, 608-621.

Stephenson SL. 2003 - Myxomycetes of New Zealand. Fungal Diversity Press, Hong Kong.

Stephenson SL. 2011 - From morphological to molecular: studies of myxomycetes since the publication of the Martin and Alexopoulos monograph. Fungal Diversity 50, 21-34.

Stephenson SL, Kalyanasundaram I, Lakhanpal TN. 1993 - A comparative biogeographical study of myxomycetes in the mid-Appalachians of eastern North America and two regions of India. Journal of Biogeography 20, 645-657.

Stephenson SL, Stempen H. 1994 - Myxomycetes: a Handbook of Slime Molds. Timber Press, Portland, Oregon.

Tran HTM, Stephenson SL, Hyde KD, Mongkolporn O. 2006 - Distribution and occurrence of myxomycetes in tropical forests of northern Thailand. Fungal Diversity 22, 227-242. 
UNESCO. 2001 - Cat Tien Biosphere Reserve Management Board and the Cat Tien Biosphere Reserve Council. Internal Report.

van Hooff JPM. 2009 - Cribraria tecta, a new myxomycete from Vietnam. Boletín de la Sociedad Micológica de Madrid 33, 129-136. 